\title{
STRATEGIC PLANNING AND BRAND MANAGEMENT ON INTERNET
}

\author{
Andrlic, B.; Budic, H. \& Novoselovic, D.
}

Abstract: Internet as medium enables business activity of the company in virtual space. Companies nowadays cope with greater difficulties arising from challenges of growing e-markets and rapidly changing factor of customers' behaviour. With increase of number of Internet users, branded products are constantly being attributed growing significance, when compared with other media, channels and surroundings. Internet should be considered from the right point of view as medium for realisation of strategic marketing goals, used for strengthening of the brand recognition, which finally results in acquiring of new customers, higher loyalty, greater market quotas and increase of sale revenues. The authors of this paper give review of theoretical views of product brands and brand value concept. Finally, strategic marketing model for the process of creation of brand equity has been reconsidered.

Key words: Internet, e- marketing, marketing strategy, brand management,brand value, web site
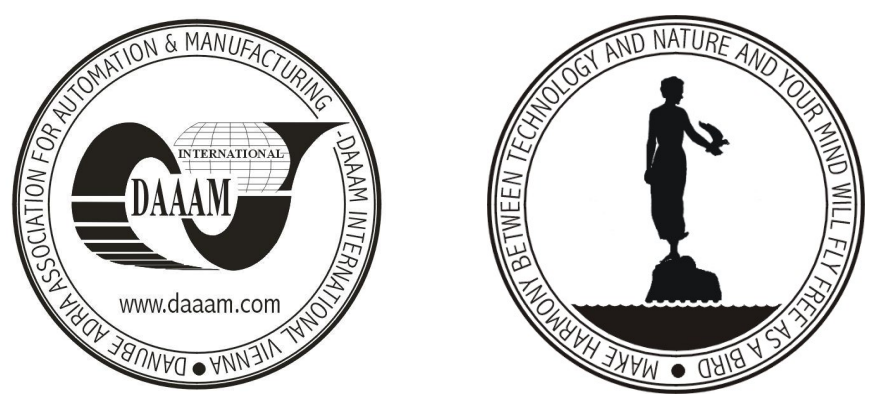

Authors' data: M.Sc. Andrlic, B[erislav]*; dipl.oec. Budic, H[rvoje]*; Mr.sc. Novoselovic; D[aniel]***,* Polytechnic Požega, S.S. Kranjčevića 1, 34000 Pozega, Croatia, ** Ministry of sea, tourism, traffic and development, Pozeska 31 a, 34322 Brestovac, Croatia, *** Mechanical Engineering Faculty in Slavonski Brod/ University in Osijek, Trg I.B.Mazuranic 2, HR-35000 Slavonski Brod, Croatia, bandrlic@vup.hr, hrvoje.budic@ws.mmtpr.hr, Daniel.Novoselovic@sfsb.hr

This Publication has to be referred as: Andrlic, B.; Budic, H. \& Novoselovic, D. (2007). Strategic planning and brand management on Internet, Chapter 10 in DAAAM International Scientific Book 2007, B. Katalinic (Ed.), Published by DAAAM International, ISBN 3-901509-60-7, ISSN 1726-9687, Vienna, Austria DOI: $10.2507 /$ daaam.scibook.2007.10 